\title{
ANALISIS KERENTANAN AIR PERMUKAAN DAS SEMBUNG, KABUPATEN SLEMAN, DIY
}

\author{
${ }^{1}$ Afid Nurkholis, ${ }^{1}$ Yuli Widyaningsih, ${ }^{1}$ Ayu Dyah Rahma, ${ }^{1}$ Amalya Suci, ${ }^{1}$ Ardian Abdillah, ${ }^{1}$ Gina Aprila \\ Wangge, ${ }^{1}$ Arum Sari Widiastuti, ${ }^{1}$ Deka Ayu Maretya \\ ${ }^{1}$ Departemen Geografi Lingkungan, Fakultas Geografi, Universitas Gadjah Mada \\ email author: afidnurkholis@gmail.com
}

\begin{abstract}
Abstrak
Kerentanan air permukaan merupakan ukuran tingkat kesulitan dan kemudahan zat tercemar untuk masuk dalam air permukaan. Analisis kerentanan air permukaan menggunakan pendekatan skoring dengan parameter kemiringan lereng, penggunaan lahan, dan curah hujan rerata tahunan. Setiap parameter diberi bobot yang berbeda tergantung dengan tingkat pengaruh terhadap kerentanan airtanah. Penelitian ini akan mengukur kerentanan air permukaan di DAS Sembung, Kabupaten Sleman. Satuan analisis yang digunakan adalah bentuklahan. DAS Sembung memiliki tiga bentuklahan, yaitu lereng kaki gunungapi, dataran kaki gunungapi, dan teras sungai. Curah hujan didapatkan dengan menghitung hujan wilayah menggunakan metode isohyet. Kemiringan lereng diolah dari data kontur Peta RBI skala 1:25.000. Penggunaan lahan juga didapatkan dari Peta RBI tersebut. Hasil penelitian menunjukkan bahwa tingkat kerentanan DAS Sembung pada lereng kaki dan dataran kaki tergolong rentan sedangkan pada teras sungai tergolong agak rentan. Hal ini disebabkan karena penggunaan lahan pada lereng kaki dan dataran kaki lebih rentan mengalami degradasi air permukaan. Kedua bentuklahan memiliki penggunaan lahan dominan berupa permukiman dan sawah. Sementara itu, bentuklahan teras sungai memiliki penggunaan lahan dominan kebun campuran. Parameter curah hujan dan lereng pada ketiga bentuklahan relatif homogen, sehingga faktor paling sensitif dalam menentukan kerentanan air permukaan di DAS Sembung adalah penggunaan lahan.
\end{abstract}

kata kunci: kerentanan DAS, DAS Sembung, sumberdaya air, air permukaan

\section{Sitasi model APA}

Nurkholis, A., Widyaningsih, Y., Rahma, A. D., Suci, A., Abdillah, A., Wangge, G. A., Widiastuti, A. S., Maretya, D. A. (2016, March 30). Analisis Kerentanan Air Permukaan DAS Sembung, Kabupaten Sleman, DIY. http://doi.org/10.17605/OSF.IO/K54BE 


\section{PENDAHULUAN}

Kerentanan terhadap air berhubungan dengan tingkat kemudahan zat pencemar untuk mempengaruhi kualitas air, baik air permukaan maupun airtanah. Kontaminasi dari faktor fisik dan non fisik dapat menjadi salah satu penyebab yang akan merubah kualitas air. Pencemaran adalah proses masuk/dimasukkannya makhluk hidup, zat, energi dan atau. komponen lain ke dalam lingkungan hidup hingga melebihi batas ambang baku mutu lingkungan yang telah ditetapkan (UU No. 32 Tahun 2009 tentang Perlindungan dan Pengelolaan Lingkungan Hidup).

Kerentanan air permukaan merupakan ukuran tingkat kesulitan dan kemudahan zat tercemar untuk masuk dalam air permukaan. Hal yang membedakan antara kerentanan airtanah dan air permukaan adalah skor dari variabel dan bobot dari parameter yang digunakan untuk menilai kerentanan (Harter dan Larry, 2008 dalam Husein dan Werdiningsih, 2012).

Husein dan Werdiningsih (2012) melakukan penelitian mengenai kerentanan air permukaan di Subdas Blongkeng dengan menggunakan pendekatan PCSM (Point Count System Model). Analisis kerentanan air permukaan menggunakan pendekatan skoring dengan parameter kemiringan lereng, penggunaan lahan, dan curah hujan rerata tahunan. Setiap parameter diberi bobot yang berbeda tergantung dengan tingkat pengaruh terhadap kerentanan airtanah. Faktor kemiringan lereng akan berpengaruh pada banyaknya presipitasi yang menjadi runoff atau proses infiltrasi yang terjadi. Penggunaan lahan mempengaruhi aktivitas yang terjadi di permukaan tanah, sehingga mempengaruhi kecenderungan air yang menjadi runoff. Sementara faktor curah hujan akan menentukan besarnya jumlah sumber air yang tertransport melalui permukaan lahan menuju sungai atau danau.

Penelitian ini akan mengukur kerentanan air permukaan di DAS Sembung. DAS Sembung terletak di Kabupaten Sleman yang secara fisiografis berada pada lereng kaki Gunung Merapi. Wilayah ini merupakan kawasan yang berpotensi untuk dibangun karena memiliki kemampuan dan kesesuaian lahan yang baik. (Nurkholis, dkk 2016). Oleh karena itu, pengukuran terhadap kerentanan air permukaan perlu dilakukan untuk perencanaan pembangunan.

\section{WILAYAH KAJIAN}

DAS Sembung merupakan bagian dari DAS Opak. DAS Sembung dibagi menjadi tiga zonasi yaitu hulu, tengah, dan hilir. Penutup lahan yang dominan di DAS Sembung yaitu sebagai pertanian, perkebunan, dan permukiman. Klasifikasi lereng di DAS Sembung berupa lereng yag datar dan landai. Formasi batuan yang terdapat pada DAS Sembung berupa Qmi/ Qvu3 yaitu 
Endapan Volkanik Merapi Muda yang terdiri dari tuff, abu, breksi, aglomerat, dan leleran lava tak terpisahkan. Formasi ini berhulu pada Gunungapi Merapi dan menyusun sebagian besar lereng Gunung Merapi. Formasi berumur kuarter dan masih terus mengalami proses erupsi. Material yang tersusun merupakan hasil dari akumulasi erupsi Gunung Merapi. DAS Sembung memiliki tiga bentuklahan, yaitu lereng kaki volkanik, dataran kaki volkanik, dan teras sungai (Gambar 2.1).

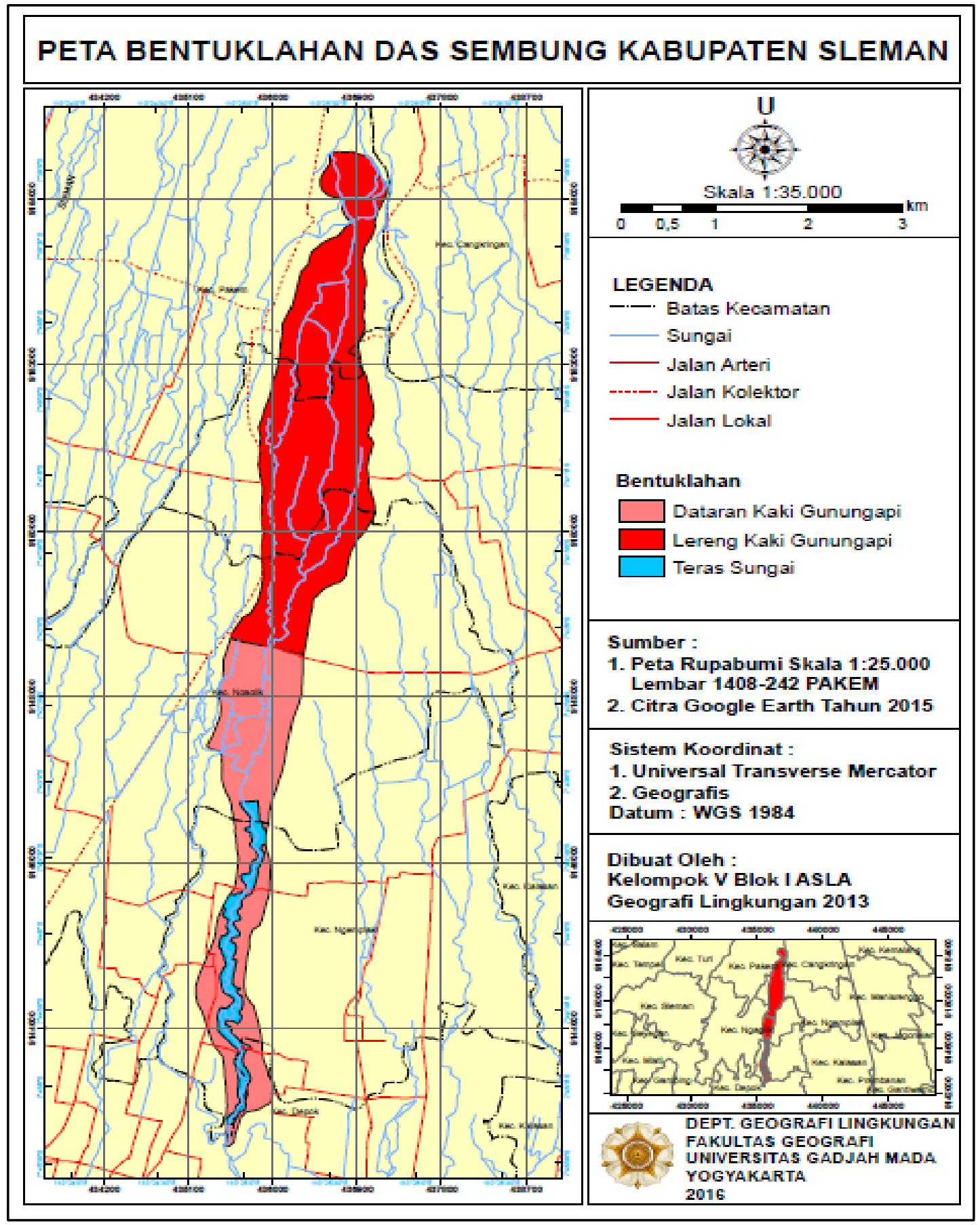

Gambar 2.1. Peta Bentuklahan DAS Sembung 


\section{METODE PENELITIAN}

Penaksiran tingkat kerentanan DAS terhadap pencemaran dilakukan dengan metode PCSM (Point Count System Model). Metode ini menekankan pada pembobotan tiap parameter dan skor dari tiap variabel yang digunakan atau dikenal juga dengan metode pembobotan dan penilaian (Parameter Weighting and Rating Method) (Gambar 3.10).

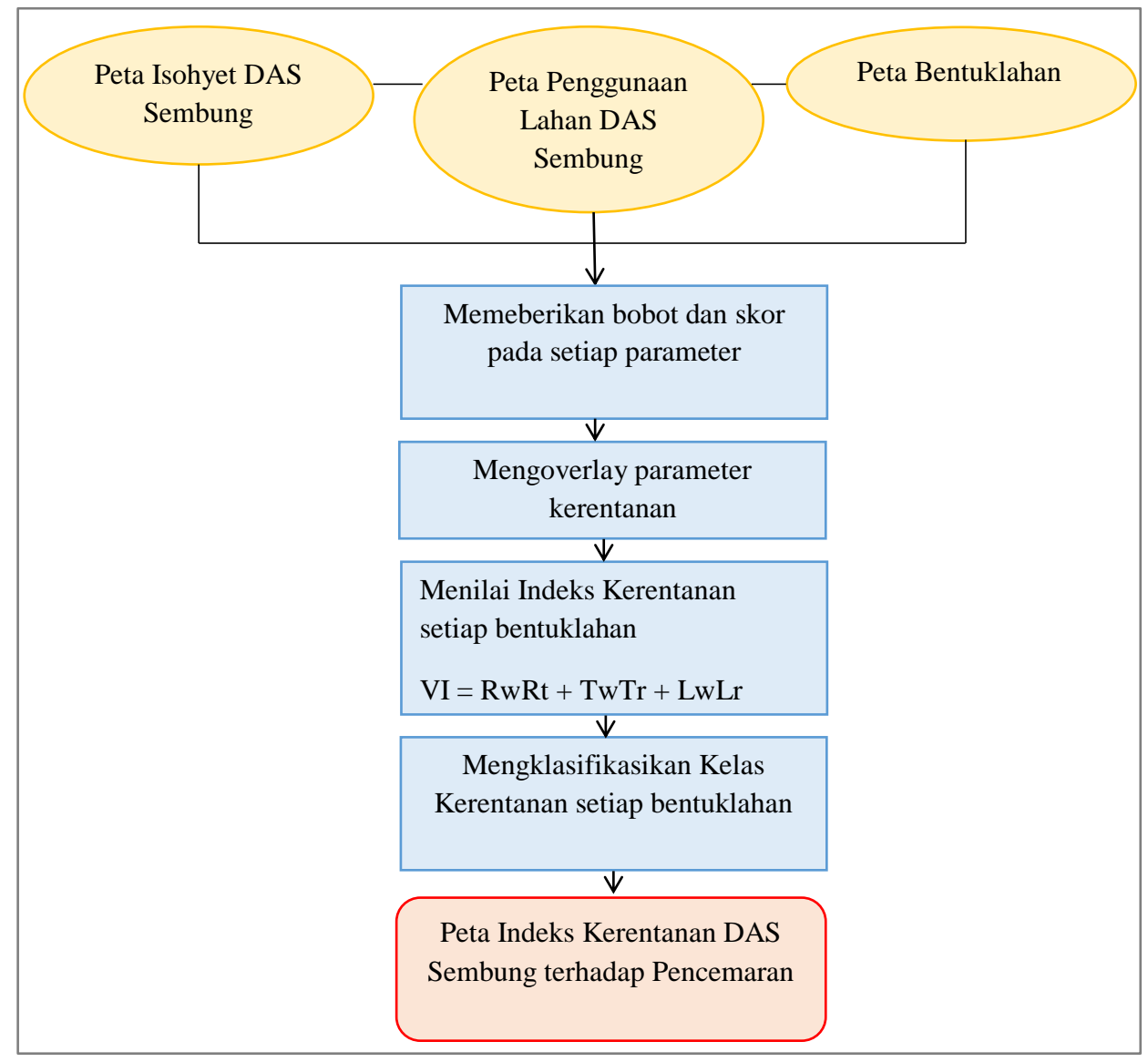

Gambar 3.10. Perhitungan Kerentanan Air Permukaan

Penentuan indeks kerentanan air permukaan dalam penelitian ini menggunakan tiga parameter, yaitu kemiringan lereng, penggunaan lahan, dan curah hujan (Tabel 3.1 - 3.4). Setiap parameter yang digunakan akan diberi bobot dengan rentang. Variabel dari parameter yang digunakan diberi skor 1-10. Skor yang tinggi dari suatu variabel menggambarkan semakin rentan variabel tersebut terhadap pencemaran dan berlaku sebaliknya. 
Tabel 3.1 Pembobotan Parameter Kerentanan DAS

\begin{tabular}{|l|r|}
\hline \multicolumn{1}{|c|}{ Parameter } & Bobot \\
\hline Penggunaan Lahan & 3 \\
\hline Kemirigan Lereng & 1 \\
\hline Curah Hujan & 2 \\
\hline
\end{tabular}

Sumber : Modifikasi dari Eimers, et al. (2000)

Tabel 3.2 Skoring Parameter Penggunaan Lahan

\begin{tabular}{|c|c|}
\hline Penggunaan Lahan & Skor \\
\hline Tubuh Air & 1 \\
\hline Semak Belukar & 4 \\
\hline Kebun & 5 \\
\hline Tegalan & 6 \\
\hline Sawah & 7 \\
\hline Permukiman & 8 \\
\hline
\end{tabular}

Sumber : Modifikasi dari Eimers, et al. (2000)

Tabel 3.3 Skoring Parameter Kemiringan Lereng

\begin{tabular}{|c|c|}
\hline Kemiringan Lereng (\%) & Skor \\
\hline$<8$ & 2 \\
\hline $8-15$ & 4 \\
\hline $15-25$ & 6 \\
\hline
\end{tabular}

Sumber : Modifikasi dari Eimers, et al. (2000)

Tabel 3.4 Skoring Parameter Curah Hujan

\begin{tabular}{|c|c|}
\hline Curah Hujan (mm) & Skor \\
\hline $1500-2000$ & 5 \\
\hline $2000-2500$ & 7 \\
\hline $2500-3000$ & 9 \\
\hline$>3000$ & 10 \\
\hline
\end{tabular}

Sumber : Modifikasi dari Eimers, et al. (2000)

Penaksiran terhadap kerentanan DAS dilakukan pada setiap bentuklahan berdasarkan parameter yang terdapat pada setiap bentuklahan. Pemberian bobot dan skor setiap parameter dilakukan menggunakan bantuan ArcGIS. Sehingga dapat diketahui Indeks Kerentanan DAS terhadap pencemaran dengan rumus : 


$$
\mathrm{VI}=\mathrm{RwRt}+\mathrm{TwTr}+\mathrm{LwLr}
$$

$$
\begin{array}{llrl}
\mathrm{VI} & =\text { indeks kerentanan } & & \mathrm{Rw}=\text { bobot curah hujan } \\
\mathrm{Rt} & =\text { skor curah hujan } & & \mathrm{Tw}=\text { bobot kemiringan lereng } \\
\mathrm{Tr} & =\text { skor kemiringan lereng } & \mathrm{LW}=\text { bobot penggunaan lahan } \\
\mathrm{Lt}=\text { skor penggunaan lahan. } & &
\end{array}
$$

Penentuan kelas kerentanan berdasarkan nilai Indeks kerentanan diperoleh berdasarkan klasifikasi Tabel 3.5.

Tabel 3.5 Kelas Kerentanan DAS terhadap Pencemaran

\begin{tabular}{|l|c|}
\hline \multicolumn{1}{|c|}{ Kelas } & \multicolumn{2}{|c|}{ Interval } \\
\cline { 1 - 1 } tidak rentan & $15-22$ \\
\cline { 1 - 1 } agak rentan & $22-29$ \\
\cline { 1 - 1 } Rentan & $29-36$ \\
\cline { 1 - 1 } cukup rentan & $36-43$ \\
\cline { 1 - 1 } sangat rentan & $43-50$ \\
\hline
\end{tabular}

\section{HASIL DAN PEMBAHASAN}

Penaksiran kerentanan air di DAS Sembung dilakukan menggunakan menggunakan metode PCSM. Parameter lereng yang semakin terjal menyebabkan tingkat kerentanan semakin tinggi. Kemiringan lereng yang terjal akan mempercepat laju pencampuran polutan ke dalam air karena aliran air yang semakin cepat dan proses turbulensi terjadi. Begitu pula dengan paramter curah hujan rerata tahunan yang semakin tinggi pada suatu wilayah maka tingkat kerentanan semakin tinggi. Air hujan merupakan media pelarut dan pembawa poutan ataupun sedimen yang berada di permukaan melalui runoff dan infiltrasi. Penggunaan lahan yang rentan terhadap kerentanan air adalah permukiman, sawah dan tegalan. Hal ini dikarenakan ketiga jenis pengunaan lahah ini berpotensi menghasilkan limbah baik limbah domestik ataupun limbah yang dihasilkan dari pelarutan pupuk yang digunakan.

Wilayah DAS Sembung merupakan wilayah yang seragam. Hal ini digambarkan oleh curah hujan rerata tahunannya yang bernilai $2049 \mathrm{~mm} / \mathrm{th}$. Sementara itu, kemiringan lereng juga seragam (0-8\% dengan topografi datar hingga landai). Kemiringan lereng 0-3\% terdapat pada bentuklahan Dataran Kaki Gunungapi dan sebagian Teras Sungai (Tabel 4.2 dan 4.3). Kemiringan Lereng 38\% terdapat pada bentuklahan Lereng Kaki Gunungapi dan sebagian Teras Sungai (Tabel 4.1). 
Variasi penggunaan lahan pada DAS Sembung terdiri dari permukiman, sawah irigasi, kebun, dan tegalan. Hal ini menyebakan jenis penggunaan lahan merupakan parameter yang paling mempengaruhi kondisi kerentanan air di DAS Sembung

Tabel 4.1. Kelas Kerentanan pada Lereng Kaki di DAS Sembung

\begin{tabular}{|c|c|c|c|c|c|c|}
\hline \multicolumn{7}{|c|}{ LERENG KAKI } \\
\hline No & Parameter & $\begin{array}{l}\text { Kriteria di } \\
\text { Lapangan }\end{array}$ & Nilai & Bobot & Nilai*Bobot & Kelas \\
\hline 1 & Curah Hujan & 2000 & 5 & 2 & 10 & \multirow{4}{*}{ Rentan } \\
\hline 2 & Lereng & $3-8 \%$ & 2 & 1 & 2 & \\
\hline 3 & $\begin{array}{l}\text { Penggunaan } \\
\text { Lahan }\end{array}$ & $\begin{array}{c}\text { sawah } \\
\text { irigasi, } \\
\text { tegalan, } \\
\text { kebun, } \\
\text { permukiman }\end{array}$ & 7,3 & 3 & 21,9 & \\
\hline \multicolumn{5}{|c|}{ Jumlah } & 33,9 & \\
\hline
\end{tabular}

Tabel 4.2. Kelas Kerentanan pada Dataran Kaki di DAS Sembung

\begin{tabular}{|c|c|c|c|c|c|c|}
\hline \multicolumn{7}{|c|}{ DATARAN KAKI } \\
\hline No & Parameter & $\begin{array}{l}\text { Kriteria di } \\
\text { Lapangan }\end{array}$ & Nilai & Bobot & Nilai*Bobot & Kelas \\
\hline 1 & Curah Hujan & 2000 & 5 & 2 & 10 & \multirow{4}{*}{ Rentan } \\
\hline 2 & Lereng & $0-3 \%$ & 2 & 1 & 2 & \\
\hline 3 & $\begin{array}{l}\text { Penggunaan } \\
\text { Lahan }\end{array}$ & $\begin{array}{c}\text { sawah irigasi, } \\
\text { kebun dan } \\
\text { permukiman }\end{array}$ & 7,4 & 3 & 22,2 & \\
\hline \multicolumn{5}{|c|}{ Jumlah } & 34,2 & \\
\hline
\end{tabular}

Tabel 4.3. Kelas Kerentanan pada Teras Sungai di DAS Sembung

\begin{tabular}{|c|c|c|c|c|c|c|}
\hline \multicolumn{7}{|c|}{ TERAS SUNGAI } \\
\hline No & Parameter & $\begin{array}{l}\text { Kriteria di } \\
\text { Lapangan }\end{array}$ & Nilai & Bobot & Nilai*Bobot & Kelas \\
\hline 1 & Curah Hujan & 2000 & 5 & 2 & 10 & \multirow{3}{*}{$\begin{array}{c}\text { Agak } \\
\text { Rentan }\end{array}$} \\
\hline 2 & Lereng & 8-Mar & 2 & 1 & 2 & \\
\hline 3 & $\begin{array}{l}\text { Penggunaan } \\
\text { Lahan }\end{array}$ & Kebun & 5 & 3 & 15 & \\
\hline \multicolumn{5}{|c|}{ Jumlah } & 27 & \\
\hline
\end{tabular}

DAS Sembung memiliki tingkat kerentanan agak rentan hingga rentan (Gambar 4.1). Kategori agak rentan hanya terdapat pada Bentuklahan Teras Sungai di DAS Sembung. Hal ini disebabkan oleh penggunaan lahan didominasi kebun campuran yang minim pengolahan oleh 
manusia dan tidak berpotensi menghasilkan limbah. Bentuklahan Teras Sungai ini memiliki penggunaan lahan dominan berupa kebun pada seluruh wilayahnya. Ketegori rentan terdapat pada bentuklahan Lereng Kaki Gunungapi dan Dataran Kaki Gunungapi. Jenis penggunaan lahan di Dataran Kaki Gunungapi dan Lereng Kaki Gunungapi didominas oleh sawah irigasi dan permukiman. Penggunaan lahan sawah dan permukiman merupakan jeni penggunaan lahan yang rentan terhadap pencemaran. Limbah yang dihasilkan akan lebih tinggi jika dibandingkan dengan limbah yang dhasilkan oleh jenis penggunaan lahan lainnya. Limbah-limbah yang dihasilkan biasanya berbentuk padat, cair atau gas. Limbah yang dhasilkan oleh permukiman biasanya adalah limbah domestik. Limbah ini mampu masuk ke dalam sistem airtanah dengan media air (infiltrasi dan perkolasi).

Kondisi DAS Sembung yang didominasi permukiman dan sawah irigasi menyebabkannya rentan terhadap pencemaran. Oleh karenanya, perlu adanya pola pengelolaan limbah pada wilayah DAS Sembung untuk mencegah meningkatnya limbah yang terbuang ke dalam sistem. Terutama tingkat kesesuaian lahan di DAS Sembung untuk permukiman dan pertanian yang tinggi menjadi salah satu faktor pendorong perlunya pengelolaan limbah di DAS Sembung. Pegelolaan limbah dapat dilakukan secara individu atau kelompok secara terpadu. Salah satunya dengan adanya pembangunan septictank secara kolektif, pembuangan sampah yang terorganisir, dan pembangunan IPAL serta perlunya arahan pegolahan lahan yang benar bagi para petani agar beban pencemar yang masuk akibat penggunaan pestidisida lebih dapat dikendalikan.

\section{KESIMPULAN}

Tingkat kerentanan DAS Sembung pada lereng kaki dan dataran kaki tergolong rentan sedangkan pada teras sungai tergolong agak rentan. Hal ini disebabkan karena penggunaan lahan pada lereng kaki dan dataran kaki lebih rentan mengalami degradasi air permukaan. Kedua bentuklahan memiliki penggunaan lahan dominan berupa permukiman dan sawah. Sementara itu, bentuklahan teras sungai memiliki penggunaan lahan dominan kebun campuran. Parameter curah hujan dan lereng pada ketiga bentuklahan relatif homogen, sehingga faktor paling sensitif dalam menentukan kerentanan air permukaan di DAS Sembung adalah penggunaan lahan. Penggunaan lahan yang tidak sesuai dengan RTRW dan sistem pengelolaan yang kurang sesuai akan semakin memperburuk kondisi DAS. 


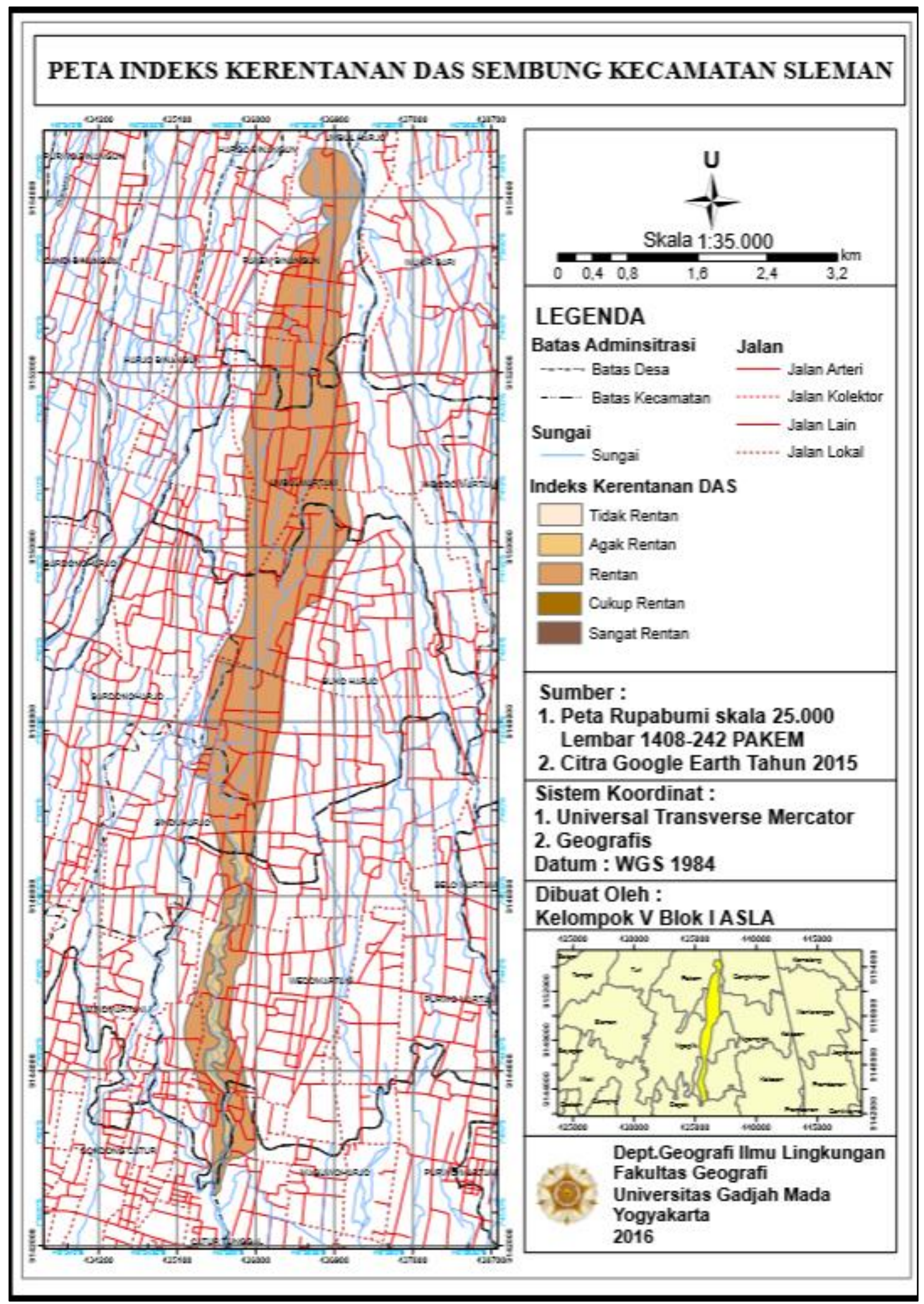

Gambar 4.1. Peta Kerentanan DAS Sembung 


\section{DAFTAR PUSTAKA}

Anonim. UU No. 32 Tahun 2009 Tentang Perlindungan dan Pengelolaan Lingkungan Hidup

Eimers, J. L., Weaver, J. C., Terziotti, S., \& Midgette, R. W. (2000). Methods of Rating Unsaturated Zone and Watershed Characteristics of Public Water Supplies in North Carolina. North Carolina. Retrieved from:

https://pubs.usgs.gov/wri/wri994283/pdf/report.pdf

Husein, S dan Werdiningsih. 2012. Pemanfaatan Sistem Informasi Geografis (SIG) Berbasis Open Source Untuk Analisis Kerentanan Air Permukaan Subdas Blongkeng. Prosiding Seminar Nasional Teknologi Informasi dan Komunikasi 2012 (SENTIKA 2012).

Nurkholis, A., Widyaningsih, Y., Rahma, A. D., Suci, A., Abdillah, A., Wangge, G. A., Widiastuti, A. S., Maretya, D. A. (2016, March 30). Analisis Kemampuan dan Kesesuaian Lahan di Das Sembung, Kabupaten Sleman, DIY. http://doi.org/10.17605/OSF.IO/M9DKN 